\title{
Global and National Scenario and Growth Trends in Area Production Productivity and Export of Fruits and Vegetables
}

\author{
A. Ananthakumar ${ }^{1}$, C. Sekhar ${ }^{2 *}$ and D. Murugananthi ${ }^{3}$ \\ ${ }^{1}$ Department of Social Sciences, Agricultural College and Research Institute, \\ Killikulam, Thoothukkudi District, India \\ ${ }^{2}$ Department of Agricultural Economics, TNAU, Coimbatore - 641 003, India \\ ${ }^{3}$ Department of Agricultural and Rural Management, TNAU, Coimbatore - 641 003, India \\ *Corresponding author
}

\section{A B S T R A C T}

Keywords

Fruits and vegetables, Area production and productivity, Export of fruits

Article Info

Accepted:

17 October 2019

Available Online:

10 November 2019
This paper aimed at addressing the area production and productivity scenario in respect of fruits and vegetables focusing Banana as the principal crop and the Onion as the principal crop. Indian Productivity is comparatively less when examining the few of the state's average productivity. Maharashtra and Gujarat are the states have given highest productivity to the level of 65 tonnes per ha. Whereas, Tamil Nadu is very poor in augmenting productivity on par with the leading states in India. From that one could understand that the technology gap is visible and hence the Department of Horticulture and plantation crops have to take special efforts in attaining the higher productivity by taking the farmers on exposure visits to gain higher productivity. Besides, export of fruits and vegetables and their growth rates were assessed and forecasted for the year 2020 .

\section{Introduction}

Horticulture development had not been a priority until recent years in India. During the period 1948-80, the main focus of the country was on cereals. During 1980-92 there was consolidation of institutional support and a planned process for the development of horticulture then started. It was later in the post-1993 period that a focused attention was given to horticulture development through an enhancement of plan allocation and knowledge based technology adoption practices. Giving a fillip to Horticultural Education was also given much importance and technology dissemination practices become widespread. National Horticulture Mission was launched in April 2005 as a 
centrally sponsored scheme to promote holistic growth of the horticulture sector through an area based regionally differentiated strategies. The foreign trade policy in 2004-09 emphasized the need to boost agricultural exports, growth and promotion of export of horticultural products. Horticultural sector contributes 28 per cent of Agriculture Gross Domestic Product and 54 per cent of Agricultural Exports in India (2007-08). The sector is growing at an average growth rate of 3.6 per cent over the last decade.

The Fruits and Vegetables (F\&V) sector has been a driving force in stimulating a healthy growth trend in Indian Agriculture. Given the rising share of high value commodities in the total value of agricultural output and their growth potential, this segment is likely to drive agricultural growth in the years to come. It plays a unique role in India's economy by improving the income of the rural people. Cultivation of these crops is labor intensive and as such they generate lot of employment opportunities for the rural population.

The Fruits and Vegetable sector is perhaps the most profitable venture of all farming activities as it provides ample employment opportunities and scope to raise the income of the farming community and the dependent traders in the field of horticulture. It also has tremendous potential to push the overall agriculture growth. India has been bestowed with wide range of climate and physicalgeographical conditions and as such is most suitable for growing various kinds of Fruits and Vegetables. This has placed India among the foremost countries in Fruits and Vegetables production just behind China. Fruits and Vegetables together constitute about 92 per cent of the total horticultural production in India. Though this scenario is an encouraging one, the status of area production and productivity of fruits are whether increasing in its magnitude or decreasing is not known. Moreover, it should be a continuous update so as to communicate the planners and advisors in agriculture and horticulture to highlight the status so that they will appraise the same in the suitable forum to promote the area production and productivity of fruits and vegetables and hence this paper.

\section{Design of the study}

To address the production and productivity scenario of fruits and vegetables globally and national level, the secondary data on area production and productivity were relied upon. The secondary data published in the Horticultural Statistics at a Glance -2016 and 2018 and Agricultural Statistics at a Glance 2016 were referred and the data were used for analysis using Compound Annual Growth Rate for predicting the futuristic values on production and productivity of fruits and vegetables.

\section{Growth rate}

To forecast the area, production and productivity of Banana and the Onion crops during 2018 and 2020, the Compound Growth Rate analysis was used by utilizing the time series data available between 2006 to 2017 in respect of Tamil Nadu and India. Similar methodology was also used by Muthupandi et.al during 2019.

Compound growth rate (CGR) formula of the following form was used for analyzing the growth rate. The form of the equation is

$Y=a b^{t} e_{t}------1$

Where,

$Y=$ Dependent variable for which growth rate is estimated

$\mathrm{a}=$ Intercept 
$\mathrm{b}=$ Regression co-efficient

$\mathrm{t}=$ Time variable

$\mathrm{e}=$ Error term

The compound growth rate was obtained using the logarithmic form of the equation (1) as detailed below.

In $\mathrm{Y}=\ln a+\ln b$

Then, compound growth rate (r) in per cent was computed by using the relationship

$r=[($ Antilog of $b)-1] \times 100$

The compound growth rates were tested for their significance by the statistics given by

$\mathrm{t}=\mathrm{r} / \mathrm{SE}(\mathrm{r})$

Where,

$S E(r)=[100 * b * S E(\ln b)] / \ln e$

The study on growth in area, production and productivity of major fruit and vegetable crop was purposively taken up in India. The secondary data on area under Fruits and Vegetables crops, production and productivity of crops were used to analyze the trends. The time series data on area, production, productivity of vegetables and fruits crop is available from 2006 onwards. Hence the analysis has covered the data for the period from 2006 to 2017. The growth in the area, production and productivity of Fruits and Vegetables crops were estimated.

\section{Results and Discussion}

The focus of the research is to address the production, marketing and export of fruits and vegetables in the World, the Indian subcontinent and in the state of Tamil Nadu under the following sub heads.
Global Production of Fruits and Vegetables

Area, Production and Productivity of Fruits and Vegetables in India

Area, Production and Productivity of Fruits and Vegetables in Tamil Nadu

In this context, one can better understood the position of production of fruits and vegetables by comparing the national, international and regional data and hence each section is discussed very carefully.

Global Production and Productivity of Fruits and Vegetables

In respect of Global production and productivity assessment, the Banana was taken as the principal crop and the same was discussed as under.

Global production and productivity of banana

The focus of the study is centered on the Banana fruit, its production and productivity at International level, National and Regional level are to be discussed. Table 1 is containing the information on Banana fruit and its production across the leading nations.

Table 1 revealed that India is the topper in producing Banana globally by achieving the record production of 29.12 million tonnes followed by China capable of producing 13.32 million tonnes which are respectively accounting for 26.14 per cent and 11.96 per cent to the total global production of Banana.

In respect of Productivity of Banana, Indonesia is the country found to generate highest productivity globally to the tune of 50.06 tonnes per ha followed by Guatemala achieved 48.27 tonnes of productivity of Banana and ranking second globally. The Production of Banana in found to be lower in 
the countries like Philippines, Brazil and Burundi. But the countries like India and China whom are the global leaders in production of Banana should learn the method of producing the highest productivity of 50tonnes per ha and hence the scientists of Tamil Nadu Agricultural University and the State Agricultural Universities in India should find the ways and means of translating the art and science of producing such higher out turn of productivity. For that the Ministry of Agriculture, Government of India and the Government of Tamil Nadu should take special efforts to enhance the productivity of fruits especially the Banana crop in India.

\section{Global production and productivity of onion}

Among the Vegetables, the representative crop in the study is Onion and hence the status of production and productivity was assessed at Global, National and Regional level. These details are analyzed and the results are presented in Table 2.

Table 2 revealed that China is found to be the leader in production of Onion followed by India with record production of 23.91 million tonnes and 19.42 million tonnes respectively. The United States of America found to hold the fourth place in the production of Onion leaving the third place to Egypt. It has achieved only 3.03 million tonnes. The global onion production is found to be 93.17 million tonnes. Among the total Global production of onion, China and India alone could contribute nearly 50 per cent to the total. Though United States of America is in the fourth position in respect of production of onion, the productivity level of USA found to be the highest which is estimated at 56.40 tonnes per ha followed by Iran has achieved the second highest productivity earner per ha which is arrived at 38 tonnes. Countries like Egypt, Turkey and Algeria are the other nations in achieving the next highest productivity. India is in the Eighth rank in achieving the productivity of onion and hence the countries which are poor in productivity earner should concentrate on imparting the technology of achieving the highest productivity by making an exposure visit to those countries.

Area, production and productivity of fruits and vegetables in India

\section{Area, production and productivity of fruits in India}

Global production and productivity of fruits and vegetables revealed that the country like India is lacking in productivity achievement even though it has achieved the highest production globally and hence the details on area, production and productivity is analyzed and the details are presented in Table 3.

Table 3 revealed that the area under Fruits especially Banana is increasing over a period of time and the production is also found to increase. Similarly the productivity is also increasing over the years. It might be due to the focus given by the National Horticulture Mission. Through its concerted efforts on Area expansion, technology transfer and infrastructure development, the farmers have been motivated to allocate higher area and hence the production is found to be increased. Though the productivity is also on the higher side, it is not comparable to the world level and hence one has to assess the gap in achieving the productivity and appropriate efforts need to be taken in this respect.

The percentage increase in the area under Banana between 1991-92 and 2017-18 is found to be 130.21 per cent. But the percentage area under Banana to the total area under fruits is found to be almost stagnant and found to grow only at marginal levels. The increase in production of Banana during this 
period is found to be 295.47 per cent. When we compare the same area under Banana and Production of Banana between 2001-02 and 2017-18, the growth is comparatively less due to steady growth during the later period due to continuous intervention of National Horticulture Mission, Government of India through its State Department of Horticulture and Plantation crops.

\section{Area, production and productivity of vegetables in India}

The area, production and productivity of Vegetables at all India level and the focus crop for the study, Onion and its details are analyzed and the results are presented in Table 4. As witnessed in the fruits, the scenario under vegetables is also found to be increasing both in area and production of vegetables. Similar is the trend observed in the case of Onion vegetable also. The area under vegetables in India during the year 2017-18 is arrived at 10259000 ha which is capable of producing 18.43 million tonnes. The average productivity of vegetables in India is arrived at 17.97 tonnes per ha during the year 2017-18.

Table 4 revealed that the percentage increase in area under vegetables is arrived at 66.65 per cent while the area under Onion is arrived at 259 per cent between the period 2001-02 and 2017-18. The overall growth in respect of Onion found to witness higher growth. The reasons might be due to the intervention of National Horticulture Mission concentrating area expansion programs. Similar to the area expansion, the technology development also given equal thrust to achieve higher productivity. India could achieve only 18.10 tonnes per ha as productivity of onion. When we compare the productivity of USA, it is three times lower and hence concerted effort has to be taken to enhance the productivity to reduce the import tariff on vegetables exclusively onion. In this circumstance, effort has been taken to assess the state wise area production and productivity in India to assess which state is performing better than any other. These details are presented in Table 5.

State wise area, production and productivity of fruits and vegetables in India

Though India is blessed with 35 states including Union Territories, the area, production and productivity of fruits and vegetables were assessed for principal states based on the productivity of crops and the details are presented in Table 5. Since these data for all the districts does not convey much meaning to this study due to erratic variation in productivity and hence the top ten states were assessed with their productivity in Fruits like Banana and the analyzed data are presented in detail for discussion.

The productivity of fruits in India among the top ten states is found to be ranging between 14.75 tonnes to 22.11 tonnes per ha. In respect of Banana, the productivity is ranging between 24.34 tonnes to 69.54 tonnes per ha with an average productivity of Banana is 34.86 tonnes per ha. The productivity of Banana in different states of India was assessed and the states are ranked in the ascending order based on their productivity in Banana. Among the different states, Madhya Pradesh found to be the Topper with the productivity of 69.54 tonnes per ha followed by Gujarat state generated the productivity of banana to the tune of 65.63 tonnes per ha. Maharashtra is in the third place in terms of productivity of Banana with 57.95 tonnes per ha. But Tamil Nadu could generate only 38.79 tonnes per ha of Banana which is comparatively low and ranked in Eight Place. When one could compare the productivity of Banana in different states, Tamil Nadu has to learn the experiences from Madhya Pradesh and Gujarat to achieve the highest level of 
productivity. For that the role of Department of Horticulture and Plantation Crops is very much important to translate the experiences from Madhya Pradesh and Gujarat.

\section{State wise area production and productivity of vegetables in India}

Similar to the analysis of fruits, the vegetables were also analyzed with respect to the area, production and productivity in India. Here, the total area under vegetables and the Onion vegetable selected for the study are separately analyzed and the details are presented in Table 6 . Here also, the states were ranked based on the productivity of vegetables and the results are presented for only top ten states in India for detailed discussion.

Table 6 revealed that the average productivity of vegetables in India is arrived at 17.97 tonnes per ha. The average productivity of onion in India is also arrived at 18.10 tonnes per ha. When comparing these two levels of productivity, there is no much difference in terms of productivity of vegetables and onion.

On ranking the states based on the productivity obtained in respect of Onion, the Sikkim state found to be the topper with 56.45 tonnes per ha followed by Madhya Pradesh with 24.53 tonnes per ha of onion. The states like Gujarat, Haryana, Bihar, Punjab and Andhra Pradesh could generate almost equal level of productivity of Onion that stands at around 22 tonnes per ha. Only marginal differences in fractions could be found across these states revealed that the agro-climatic factors which influence the productivity of Onion is almost uniform keeping the inputs used assumed to be constant. Among the southern states, the states like Telangana and Karnataka are found to secure the Productivity of Onion on par with all India counterparts.

But the Tamil Nadu is the only state capable of producing very meagre level of productivity in Onion and hence concerted efforts should be taken up by the Department of Horticulture and Plantation Crops of Government of Tamil $\mathrm{Nadu}$ to elevate the productivity level of Onion and other crops in respect of vegetables.

District wise area, production and productivity of fruits and vegetables in Tamil Nadu

Under this head, the area, production and productivity of fruits and vegetables are discussed on the following titles.

Area, Production and Productivity of Fruits in Tamil Nadu

Area, Production and Productivity of Vegetables in Tamil Nadu

Area, production and productivity of fruits in Tamil Nadu

In the preceding sections, Tamil Nadu is found to be the poor State in achieving productivity of fruits and vegetables and only the States like Madhya Pradesh and Gujarat found to occupy the top positions in terms of productivity. In this situation, Tamil Nadu state and its productivity of Fruits across different districts were analyzed and the analyzed data is restricted to top ten districts capable of securing highest productivity in fruits and the details are presented in Table 7. 
Table.1 International production and productivity of banana (in million tonnes during 20152016)

\begin{tabular}{|c|c|c|c|c|}
\hline $\begin{array}{c}\text { Sl. } \\
\text { No }\end{array}$ & $\begin{array}{c}\text { Name of the } \\
\text { Country }\end{array}$ & $\begin{array}{c}\text { Production in Million } \\
\text { Tonnes }\end{array}$ & $\begin{array}{c}\text { Productivity in } \\
\text { Tonnes per Ha }\end{array}$ & $\begin{array}{c}\text { Percentage To } \\
\text { World Total }\end{array}$ \\
\hline $\mathbf{0 1}$ & India & 29.12 & 34.43 & 26.14 \\
\hline $\mathbf{0 2}$ & China & 13.32 & 30.98 & 11.96 \\
\hline $\mathbf{0 3}$ & Philippines & 05.83 & 12.77 & 05.23 \\
\hline $\mathbf{0 4}$ & Brazil & 06.76 & 14.40 & 06.06 \\
\hline $\mathbf{0 5}$ & Ecuador & 07.01 & 38.86 & 06.29 \\
\hline $\mathbf{0 6}$ & Indonesia & 07.01 & 50.06 & 06.29 \\
\hline $\mathbf{0 7}$ & Guatemala & 03.78 & 48.27 & 03.39 \\
\hline $\mathbf{0 8}$ & Angola & 03.86 & 29.35 & 03.46 \\
\hline $\mathbf{0 9}$ & Burundi & 00.91 & 04.67 & 00.81 \\
\hline $\mathbf{1 0}$ & Others & 33.77 & 16.89 & 30.32 \\
\hline & World Total & $\mathbf{1 1 1 . 3 7}$ & $\mathbf{2 0 . 6 2}$ & $\mathbf{1 0 0 . 0 0}$ \\
\hline
\end{tabular}

Table.2 Global production and productivity of onion (in million tonnes during 2015-2016)

\begin{tabular}{|c|c|c|c|c|}
\hline $\begin{array}{c}\text { Sl. } \\
\text { No }\end{array}$ & Name of the Country & $\begin{array}{c}\text { Production of Onion } \\
\text { in Million Tonnes }\end{array}$ & $\begin{array}{c}\text { Productivity in } \\
\text { Tonnes per Ha }\end{array}$ & $\begin{array}{c}\text { Percentage To } \\
\text { World Total }\end{array}$ \\
\hline $\mathbf{1}$ & China & 23.91 & 22.00 & 25.66 \\
\hline $\mathbf{2}$ & India & 19.42 & 16.81 & 20.84 \\
\hline $\mathbf{3}$ & Egypt & 03.12 & 36.71 & 03.34 \\
\hline $\mathbf{4}$ & USA & 03.03 & 56.40 & 03.25 \\
\hline $\mathbf{5}$ & Iran & 02.35 & 37.95 & 02.52 \\
\hline $\mathbf{6}$ & Turkey & 02.12 & 32.32 & 02.27 \\
\hline $\mathbf{7}$ & Russian Federation & 02.02 & 22.85 & 02.16 \\
\hline $\mathbf{8}$ & Pakistan & 01.74 & 12.80 & 01.86 \\
\hline $\mathbf{9}$ & Brazil & 01.66 & 28.84 & 01.78 \\
\hline $\mathbf{1 0}$ & Algeria & 00.05 & 30.58 & 00.05 \\
\hline $\mathbf{1 1}$ & Others & 33.80 & 24.43 & 36.27 \\
\hline & World Total & $\mathbf{9 3 . 1 7}$ & $\mathbf{1 8 . 8 0}$ & $\mathbf{1 0 0 . 0 0}$ \\
\hline
\end{tabular}


Table.3 Area, production and productivity of fruits in India (2017-18)

\begin{tabular}{|c|c|c|c|c|c|c|}
\hline \multirow[t]{2}{*}{ Year } & \multicolumn{3}{|c|}{ Banana } & \multicolumn{3}{|c|}{ Total Fruits } \\
\hline & $\begin{array}{c}\text { Area in '000 } \\
\text { Ha }\end{array}$ & $\begin{array}{l}\text { Production in } \\
\text { '000 Tonnes }\end{array}$ & $\begin{array}{l}\text { Productivity in } \\
\text { Tonnes per Ha }\end{array}$ & $\begin{array}{c}\text { Area in '000 } \\
\text { Ha }\end{array}$ & $\begin{array}{c}\text { Production in } \\
\text { '000 Tonnes }\end{array}$ & $\begin{array}{l}\text { Productivity in } \\
\text { Tonnes per Ha }\end{array}$ \\
\hline 1991-92 & $\begin{array}{l}383.90 \\
(13.36)\end{array}$ & $\begin{array}{c}7790.00 \\
(27.21)\end{array}$ & 20.30 & 2874.00 & 28632.00 & 9.96 \\
\hline 2001-02 & $\begin{array}{l}466.20 \\
(11.62)\end{array}$ & $\begin{array}{c}14209.90 \\
(33.04)\end{array}$ & 30.50 & 4010.00 & 43001.00 & 10.72 \\
\hline 2005-06 & $\begin{array}{l}569.50 \\
(10.70)\end{array}$ & $\begin{array}{c}18887.80 \\
(34.12)\end{array}$ & 33.20 & 5324.00 & 55356.00 & 10.40 \\
\hline 2010-11 & $\begin{array}{l}830.00 \\
(13.00)\end{array}$ & $\begin{array}{c}29780.00 \\
(39.77)\end{array}$ & 35.90 & 6383.00 & 74878.00 & 11.73 \\
\hline 2014-15 & $\begin{array}{l}880.00 \\
(13.84)\end{array}$ & $\begin{array}{c}30008.00 \\
(33.78)\end{array}$ & 34.10 & 6358.00 & 88819.00 & 13.97 \\
\hline 2017-18 & $\begin{array}{l}883.80 \\
(13.58)\end{array}$ & $\begin{array}{c}30807.50 \\
(31.64)\end{array}$ & 34.90 & 6506.00 & 97358.00 & 14.96 \\
\hline $\begin{array}{c}\text { \% Change during } \\
\text { 2017-18 over 1991- } \\
92 \\
\end{array}$ & 130.21 & 295.47 & 71.92 & 126.37 & 240.03 & 50.20 \\
\hline $\begin{array}{l}\text { \% Change during } \\
\text { 2017-18 over 2001- } \\
02\end{array}$ & 89.40 & 116.80 & 14.42 & 62.24 & 126.40 & 39.55 \\
\hline
\end{tabular}

Table.4 Area, production and productivity of vegetables in India (2017-18)

\begin{tabular}{|c|c|c|c|c|c|c|}
\hline \multirow{2}{*}{ Year } & \multicolumn{5}{|c|}{ Onion } & \multicolumn{3}{|c|}{ Total Vegetables } \\
\cline { 2 - 7 } & $\begin{array}{c}\text { Area in } \\
\text { '000 Ha }\end{array}$ & $\begin{array}{c}\text { Production } \\
\text { in } 000 \\
\text { Tonnes }\end{array}$ & $\begin{array}{c}\text { Productivity } \\
\text { in Tonnes } \\
\text { per Ha }\end{array}$ & $\begin{array}{c}\text { Area in } \\
\text { '000 Ha }\end{array}$ & $\begin{array}{c}\text { Production } \\
\text { in } 000 \\
\text { Tonnes }\end{array}$ & $\begin{array}{c}\text { Productivity } \\
\text { in Tonnes } \\
\text { per Ha }\end{array}$ \\
\hline $\mathbf{1 9 9 1 - 9 2}$ & $\begin{array}{c}331.80 \\
(5.94)\end{array}$ & $\begin{array}{c}4705.80 \\
(8.039)\end{array}$ & 14.20 & 5593.00 & 58532.00 & 10.47 \\
\hline $\mathbf{2 0 0 1 - 0 2}$ & $\begin{array}{c}495.80 \\
(8.05)\end{array}$ & $\begin{array}{c}5252.10 \\
(5.92)\end{array}$ & 10.60 & 6156.00 & 88622.00 & 14.40 \\
\hline $\mathbf{2 0 0 5 - 0 6}$ & $\begin{array}{c}703.60 \\
(9.75)\end{array}$ & $\begin{array}{c}9432.50 \\
(8.46)\end{array}$ & 13.40 & 7213.00 & 111399.00 & 15.44 \\
\hline $\mathbf{2 0 1 0 - 1 1}$ & $\begin{array}{c}1064.00 \\
(12.52)\end{array}$ & $\begin{array}{c}15118.00 \\
(10.31)\end{array}$ & 14.20 & 8495.00 & 146554.00 & 17.25 \\
\hline $\mathbf{2 0 1 4 - 1 5}$ & $\begin{array}{c}1181.00 \\
(12.38)\end{array}$ & $\begin{array}{c}18924.00 \\
(11.24)\end{array}$ & 16.00 & 9541.00 & 168300.00 & 17.64 \\
\hline $\begin{array}{c}\text { 2017-18 } \\
\text { \% Change }\end{array}$ & $\begin{array}{c}1285.00 \\
\text { during 2017-18 } \\
\text { over 1991-92 }\end{array}$ & $\begin{array}{c}23262.30 \\
(12.52)\end{array}$ & 18.10 & 10259 & 184394 & 17.97 \\
\hline $\begin{array}{c}\text { \% Change } \\
\text { during 2017-18 } \\
\text { over 2001-02 }\end{array}$ & 259.17 & 394.34 & 27.46 & 83.42 & 215.03 & 71.63 \\
\hline
\end{tabular}


Table.5 State wise area, production and productivity of fruits in India (2017-18)

\begin{tabular}{|c|c|c|c|c|c|c|}
\hline \multirow{2}{*}{ State } & \multicolumn{3}{|c|}{ Banana } & \multicolumn{3}{c|}{ Total Fruits } \\
\cline { 2 - 7 } & Area in '000 Ha & $\begin{array}{c}\text { Production } \\
\text { in'000 } \\
\text { Tonnes }\end{array}$ & $\begin{array}{c}\text { Productivity } \\
\text { in Tonnes } \\
\text { per Ha }\end{array}$ & $\begin{array}{c}\text { Area in } \\
\text { '000 Ha }\end{array}$ & $\begin{array}{c}\text { Production } \\
\text { in'000 } \\
\text { Tonnes }\end{array}$ & $\begin{array}{c}\text { Productivity } \\
\text { in Tonnes } \\
\text { per Ha }\end{array}$ \\
\hline Madhya Pradesh & $26.38(07.44)$ & 1834.03 & 69.54 & 354.10 & 7416.90 & 20.94 \\
\hline Gujarat & $68.15(16.13)$ & 4472.32 & 65.63 & 422.40 & 8996.00 & 21.29 \\
\hline Maharashtra & $80.88(10.73)$ & 4209.27 & 57.95 & 753.20 & 11728.70 & 15.57 \\
\hline Andhra Pradesh & $88.96(13.67)$ & 5003.07 & 56.24 & 650.50 & 1515.90 & 02.33 \\
\hline Uttar Pradesh & $69.38(14.55)$ & 3172.33 & 45.73 & 476.60 & 10539.80 & 22.11 \\
\hline Bihar & $31.07(10.47)$ & 1396.39 & 44.94 & 296.60 & 5117.10 & 17.25 \\
\hline Telangana & $02.29(01.37)$ & 90.02 & 39.38 & 167.10 & 1939.40 & 11.60 \\
\hline Tamil Nadu & $82.63(28.35)$ & 3205.04 & 38.79 & 291.40 & 5680.50 & 19.49 \\
\hline Chhattisgarh & $26.57(11.56)$ & 745.78 & 28.07 & 229.7 & 2666.20 & 11.60 \\
\hline West Bengal & $49.30(18.88)$ & 1200.00 & 24.34 & 261.00 & 3850.60 & 14.75 \\
\hline Total & $\mathbf{8 8 3 . 7 7}$ & $\mathbf{3 0 8 0 7 . 5 0}$ & $\mathbf{3 4 . 8 6}$ & $\mathbf{6 5 0 6 . 2 0}$ & $\mathbf{9 7 3 5 7 . 5 0}$ & $\mathbf{1 4 . 9 6}$ \\
\hline
\end{tabular}

Table.6 State wise area, production and productivity of vegetables in India (2017-18)

\begin{tabular}{|c|c|c|c|c|c|c|}
\hline \multirow{2}{*}{ State } & \multicolumn{3}{|c|}{ Onion } & \multicolumn{3}{c|}{ Total Vegetables } \\
\cline { 2 - 7 } & Area in '000 Ha & $\begin{array}{c}\text { Production } \\
\text { in '000 } \\
\text { Tonnes }\end{array}$ & $\begin{array}{c}\text { Productivity } \\
\text { in Tonnes } \\
\text { per Ha }\end{array}$ & $\begin{array}{c}\text { Area in } \\
\text { '000 Ha }\end{array}$ & $\begin{array}{c}\text { Production } \\
\text { in '000 } \\
\text { Tonnes }\end{array}$ & $\begin{array}{c}\text { Productivity } \\
\text { in Tonnes } \\
\text { per Ha }\end{array}$ \\
\hline Sikkim & $00.62(01.61)$ & 35.00 & 56.45 & 38.40 & 229.10 & 05.96 \\
\hline Madhya Pradesh & $150.87(16.95)$ & 3701.01 & 24.53 & 889.70 & 17545.50 & 19.72 \\
\hline Gujarat & $22.49(05.03)$ & 546.20 & 24.29 & 613.10 & 12254.30 & 19.80 \\
\hline Haryana & $29.93(06.69)$ & 701.50 & 23.44 & 447.00 & 7151.70 & 15.99 \\
\hline Bihar & $53.77(06.76)$ & 1240.59 & 23.07 & 824.60 & 15863.20 & 19.23 \\
\hline Punjab & $09.36(03.82)$ & 214.55 & 22.91 & 244.40 & 4919.70 & 20.12 \\
\hline Andhra Pradesh & $42.00(17.28)$ & 915.73 & 21.80 & 243.00 & 6908.30 & 28.42 \\
\hline $\begin{array}{c}\text { Himachal } \\
\text { Pradesh }\end{array}$ & $02.69(03.01)$ & 52.19 & 19.43 & 89.30 & 1811.80 & 20.28 \\
\hline $\begin{array}{c}\text { Jammu \& } \\
\text { Kashmir }\end{array}$ & $03.10(05.50)$ & 57.96 & 18.73 & 56.30 & 1226.00 & 21.77 \\
\hline $\begin{array}{c}\text { Telangana } \\
\text { Tamil Nadu (19 }\end{array}$ & $17.97(12.90)$ & 326.59 & 18.18 & 139.30 & 2753.80 & 19.76 \\
\hline Place) & $28.36(11.76)$ & 301.14 & 10.62 & 241.00 & 6396.00 & 26.53 \\
\hline Total & $\mathbf{1 2 8 4 . 9 9}$ & $\mathbf{2 3 2 6 2 . 3 3}$ & $\mathbf{1 8 . 1 0}$ & $\mathbf{1 0 2 5 9 . 1 0}$ & $\mathbf{1 8 4 3 9 4 . 3 0}$ & $\mathbf{1 7 . 9 7}$ \\
\hline
\end{tabular}

(Figures in Parentheses Indicate Percentage to Total) 
Table.7 Area, production and productivity of fruits in Tamil Nadu (2017-18)

\begin{tabular}{|c|c|c|c|c|c|c|}
\hline \multirow{2}{*}{ District } & \multicolumn{4}{|c|}{ Banana } & \multicolumn{3}{|c|}{ Total Fruits } \\
\cline { 2 - 7 } & $\begin{array}{c}\text { Area in '000 } \\
\text { Ha }\end{array}$ & $\begin{array}{c}\text { Production } \\
\text { in } \mathbf{0 0 0} \\
\text { Tonnes }\end{array}$ & $\begin{array}{c}\text { Productivity } \\
\text { in Tonnes } \\
\text { per Ha }\end{array}$ & $\begin{array}{c}\text { Area in } \\
\text { '000 Ha }\end{array}$ & $\begin{array}{c}\text { Production } \\
\text { in '000 } \\
\text { Tonnes }\end{array}$ & $\begin{array}{c}\text { Productivity } \\
\text { in Tonnes } \\
\text { per Ha }\end{array}$ \\
\hline Madurai & $2944(26.91)$ & 168205 & 57.13 & 10939 & 182436.37 & 16.67 \\
\hline Theni & $5613(31.22)$ & 311281 & 55.45 & 17976 & 490911.27 & 27.30 \\
\hline Cuddalore & $4665((68.11)$ & 252786 & 54.18 & 6849 & 287442.00 & 41.96 \\
\hline Tiruchirappalli & $6777(73.40)$ & 307781 & 45.41 & 9232 & 315224.02 & 34.14 \\
\hline Pudukkottai & $1704(57.76)$ & 69305 & 40.67 & 2950 & 73199.90 & 24.81 \\
\hline Tiruvallur & $689(05.49)$ & 22949 & 33.30 & 12544 & 41387.00 & 03.29 \\
\hline The Nilgiris & $732(82.99)$ & 24378 & 33.30 & 882 & 25664.03 & 29.09 \\
\hline Thoothukkudi & $9515(87.32)$ & 262388 & 27.57 & 10896 & 268048.16 & 24.60 \\
\hline Karur & $3350(74.57)$ & 74950 & 22.37 & 4492 & 78903.00 & 17.56 \\
\hline Thiruvarur & $689(05.49)$ & 13924 & 20.20 & 12544 & 15262 & 01.21 \\
\hline Dindigul & $3312(14.03)$ & $\mathbf{5 4 5 2 4}$ & 16.46 & 23605 & 134434 & 05.69 \\
\hline Total & $\mathbf{9 0 9 9 3}$ & $\mathbf{3 0 2 8 8 6 9}$ & $\mathbf{3 3 . 2 8}$ & $\mathbf{2 5 8 1 6 2}$ & $\mathbf{3 7 6 7 1 4 1}$ & $\mathbf{1 4 . 5 9}$ \\
\hline
\end{tabular}

(Figures in Parentheses Indicate Percentage to Total)

Table.8 Area, production and productivity of vegetables in Tamil Nadu (2017-18)

\begin{tabular}{|c|c|c|c|c|c|c|}
\hline \multirow[b]{2}{*}{ District } & \multicolumn{3}{|c|}{ Onion } & \multicolumn{3}{|c|}{ Total Vegetables } \\
\hline & Area in '000 Ha & $\begin{array}{l}\text { Production in } \\
\text { '000 Tonnes }\end{array}$ & $\begin{array}{l}\text { Productivity in } \\
\text { Tonnes per Ha }\end{array}$ & $\begin{array}{l}\text { Area in } \\
\text { '000 Ha }\end{array}$ & $\begin{array}{l}\text { Production in } \\
\text { '000 Tonnes }\end{array}$ & $\begin{array}{l}\text { Productivity in } \\
\text { Tonnes per Ha }\end{array}$ \\
\hline Coimbatore & $1372(22.31)$ & 20428 & 14.88 & 6147 & 42877 & 06.97 \\
\hline Tiruppur & $1744(29.30)$ & 24369 & 13.97 & 5991 & 43567 & 07.27 \\
\hline Theni & $775(08.45)$ & 10482 & 13.52 & 9171 & 55236 & 06.02 \\
\hline Tirunelveli & $2494(54.92)$ & 24735 & 09.91 & 4541 & 41537 & 09.14 \\
\hline Tiruchirappalli & 3384 (3796) & 27136 & 08.01 & 8914 & 242056 & 27.15 \\
\hline Namakkal & 2799 (13.59) & 22145 & 07.91 & 21269 & 456818 & 21.47 \\
\hline Perambalur & 8625 (79.69) & 59488 & 06.89 & 10822 & 104720 & 09.67 \\
\hline Dindigul & $2028(14.65)$ & 10889 & 05.36 & 13838 & 86162 & 06.22 \\
\hline Erode & $964(09.21)$ & 5117 & 05.30 & 10464 & 249528 & 23.84 \\
\hline Virudhunagar & $1507(61.63)$ & 1094 & 00.72 & 2445 & 5596 & 02.28 \\
\hline Thoothukkudi & $2873(51.96)$ & 1830 & 00.63 & 5529 & 5668 & 01.02 \\
\hline Total & 31199 & 230222 & 07.37 & 198989 & 2997244 & 15.06 \\
\hline
\end{tabular}


Table.9 Comparative analysis of area production and productivity of fruits (2017-18)

\begin{tabular}{|c|c|c|c|c|}
\hline Sl. No & Particulars & Fruits & Banana & Percentage \\
\hline \multicolumn{5}{|c|}{ All India } \\
\hline 1 & Area in $\mathrm{Ha}$ & 6505000 & 883770 & 13.58 \\
\hline 2 & Production in Tonnes & 97358000 & 30807500 & 31.65 \\
\hline 3 & $\begin{array}{l}\text { Productivity in Tonnes } \\
\text { per } \mathrm{Ha}\end{array}$ & 14.96 & 34.85 & \\
\hline \multicolumn{5}{|c|}{ Tamil Nadu State } \\
\hline 1 & Area in $\mathrm{Ha}$ & 258162 & 90993 & 35.24 \\
\hline 2 & Production in Tonnes & 3767141 & 3028869 & 80.40 \\
\hline 3 & $\begin{array}{l}\text { Productivity in Tonnes } \\
\text { per Ha }\end{array}$ & 14.59 & 33.28 & \\
\hline \multicolumn{2}{|c|}{$\begin{array}{c}\text { Percentage of Production in Tamil } \\
\text { Nadu to India }\end{array}$} & 03.86 & 09.83 & \\
\hline
\end{tabular}

Table.10 Comparative analysis of area production and productivity of vegetables

\begin{tabular}{|c|c|c|c|c|}
\hline Sl. No & Particulars & Vegetables & Onion & Percentage \\
\hline \multicolumn{5}{|c|}{ All India } \\
\hline 1 & Area in $\mathrm{Ha}$ & 10259100 & 1284990 & 12.52 \\
\hline 2 & Production in Tonnes & 184394300 & 23262330 & 11.21 \\
\hline 3 & $\begin{array}{l}\text { Productivity in Tonnes } \\
\text { per Ha }\end{array}$ & 17.97 & 18.10 & \\
\hline \multicolumn{5}{|c|}{ Tamil Nadu State } \\
\hline 1 & Area in $\mathrm{Ha}$ & 198989 & 31199 & 15.67 \\
\hline 2 & Production in Tonnes & 2997244 & 230222 & 07.68 \\
\hline 3 & $\begin{array}{c}\text { Productivity in Tonnes } \\
\text { per Ha }\end{array}$ & 15.06 & 07.37 & \\
\hline \multicolumn{2}{|c|}{$\begin{array}{c}\text { Percentage of Production in Tamil } \\
\text { Nadu in India }\end{array}$} & 01.62 & 07.37 & \\
\hline
\end{tabular}

Table.11 Quantity of fruits exported abroad from india in a decade of time (Tonnes)

\begin{tabular}{|c|c|c|c|c|c|}
\hline $\begin{array}{c}\text { Sl. } \\
\text { No }\end{array}$ & $\begin{array}{c}\text { Name of the } \\
\text { Fruit Crops }\end{array}$ & $\begin{array}{c}\text { Quantity } \\
\text { Exported during } \\
\mathbf{2 0 0 6 - 0 7}\end{array}$ & $\begin{array}{c}\text { Quantity } \\
\text { Exported during } \\
\mathbf{2 0 1 6 - 2 0 1 7}\end{array}$ & $\begin{array}{c}\text { CAGR } \\
\text { in Per } \\
\text { Cent }\end{array}$ & $\begin{array}{c}\text { Export Quantity for } \\
\text { the Year 2020-21 } \\
\text { (Predicted) }\end{array}$ \\
\hline $\mathbf{0 1}$ & Apple & 25936.00 & 22550.03 & $(-) 4.39$ & 19707.03 \\
\hline $\mathbf{0 2}$ & Banana & 11475.00 & 110750.56 & 19.37 & 188386.13 \\
\hline $\mathbf{0 3}$ & Grapes & 85562.00 & 198471.31 & 06.31 & 238512.13 \\
\hline $\mathbf{0 4}$ & Mango & 79060.00 & 52760.99 & $(-) 03.02$ & 47200.91 \\
\hline $\mathbf{0 5}$ & Orange & 30110.00 & 4811.64 & 05.52 & 56538.75 \\
\hline
\end{tabular}


Table.12 Forecasting on exports of vegetables

\begin{tabular}{|c|c|c|c|c|c|}
\hline $\begin{array}{c}\text { Sl. } \\
\text { No }\end{array}$ & $\begin{array}{c}\text { Name of } \\
\text { the } \\
\text { Vegetables }\end{array}$ & $\begin{array}{c}\text { Quantity } \\
\text { Exported during } \\
\mathbf{2 0 0 6 - 0 7}\end{array}$ & $\begin{array}{c}\text { Quantity } \\
\text { Exported during } \\
\mathbf{2 0 1 6 - 2 0 1 7}\end{array}$ & $\begin{array}{c}\text { CAGR in } \\
\text { Per Cent }\end{array}$ & $\begin{array}{c}\text { Export Quantity for } \\
\text { the Year 2020-21 } \\
\text { (Predicted) }\end{array}$ \\
\hline $\mathbf{0 1}$ & Cauliflower & 044.00 & 1338.00 & 04.98 & 01548.13 \\
\hline $\mathbf{0 2}$ & Onion & 1378837.00 & 2415739.00 & 03.02 & 2641780.15 \\
\hline $\mathbf{0 3}$ & Potato & 89024.00 & 396340.00 & 15.90 & 532475.38 \\
\hline $\mathbf{0 4}$ & Peas & 1183.00 & 1073.00 & 00.65 & 01095.00 \\
\hline $\mathbf{0 5}$ & Tomato & 33592.00 & 267515.00 & 16.92 & 427603.17 \\
\hline
\end{tabular}

Table 7 revealed that the productivity of fruits in Tamil Nadu is stands at 14.59 tonnes per ha. If one could analyze the district wise data on productivity of fruits, the Cuddalore District found to achieve the highest productivity of fruits which is arrived at $\mathbf{4 1 . 9 6}$ tonnes per ha followed by Tiruchirappalli and The NIlgiris Districts have achieved highest productivity which are accounted for 34 tonnes and 29 tonnes respectively.

In respect of Banana fruits, the Madurai District is capable of attaining 57.13 tonnes per ha followed by Theni and Cuddalore Districts found to secure 55.45 tonnes and 54.48 tonnes per ha respectively. The highest productivity could be noticed only in these three districts. All other districts taken into account in Table 7 could be able to generate the productivity of 16-45 tonnes of Banana per ha. The highest productivity of Banana in the Madurai District was mainly due to the contribution made by certain varieties including "Viruppakshi" - a hill banana which is famous among the consuming ends and capable of fetching highest price per unit of the fruits to the farmers. Though it is largely cultivated in Dindigul District, it is also practiced in the adjoining areas of Madurai District too. These will be addressed in the marketing practices in detail. The highest productivity of Banana is possible due to the fertile nature of the soil in the hills of Dindigul district and utmost care taken up by the farmers in reaping highest productivity from their Banana gardens. However, the Thoothukkudi District is the study area for the research is able to hold the $8^{\text {th }}$ Place in terms of productivity of Banana.

Area, production and productivity of vegetables in Tamil Nadu

The District wise area, production and Productivity of vegetables like Onion was also analyzed for the top ten districts of Tamil Nadu based on the productivity of Onion and the details are presented in Table 8.

Table 8 revealed that the average productivity of vegetables in Tamil Nadu was arrived at 15.06 tonnes per ha and the productivity of Onion for Tamil Nadu state as a whole was arrived at 7.37 tonnes per ha. When one could compare the productivity of overall vegetables and the productivity of Onion, it is three times lesser than the productivity of vegetables produced in the state of Tamil Nadu. In this respect, district wise details are presented for comparison.

Among the top ten districts in terms of Productivity of Onion, Coimbatore District found to be the Top runner in achieving the highest productivity of Onion with 14.88 tonnes per ha followed by Tirupur District, Theniand Tirunelveli Districts found to secure the double digit productivity which are 
respectively arrived at 13.97 tonnes, 13.52 tonnes 9.91 tonnes per ha. Thoothukkudi District is lying in between the topper and the runners with 0.63 tonnes as productivity of Onion. The runner districts secure only the productivity to the tune of 0.63 to 8.00 tonnes per ha. Though the productivity of Onion is hovering in Tamil Nadu between 5.36 tonnes to 8.01 tonnes, the highest area under Onion is found only in Dindugal District followed by Tiruppur District.

\section{Comparative analysis of area, production and productivity of fruits}

So far, we have discussed the area, production and Productivity of fruits and vegetables for India as a whole, international scenario of fruits and vegetables, the state wise scenario and the district wise scenario in Tamil Nadu. Here it is important to have a comparative discussion on productivity of fruits and vegetables in Tamil Nadu and India for better understanding to the planners and policy makers and hence these results are analyzed and the results are presented in Table 9.

Table 9 revealed that the percentage of production of Fruits in Tamil Nadu is accounted for only 3.86 per cent to total Indian production of fruits and the percentage of production of Banana in Tamil Nadu is arrived at 9.83 per cent to the total Indian Banana production. Tamil Nadu is comparatively maintaining a better status in Banana Production. In India, the average productivity of Banana is arrived at 34.85 tonnes per ha. But Tamil Nadu is capable of securing higher level of productivity which is arrived at 33.28 tonnes per ha which is an increase of 34.85 per cent over the all India level of Productivity of Banana. Similarly, Tamil Nadu is able to produce higher level of productivity in fruits which is also arrived at an increase of 14.59 per cent to Total Indian Production of Fruits.
Comparative analysis of area production and productivity of vegetables

Similar to the analysis on fruits made for Tamil Nadu and India, vegetable production scenario and productivity scenario in India and Tamil Nadu is also analyzed and the results are presented in Table 10.

Table 10 revealed that Tamil Nadu is able to obtain around 83 per cent of productivity when compared to the Indian level of productivity in overall vegetable production. The decrease in the productivity was arrived at 18 per cent over the all India level of productivity in respect of vegetables. Whereas, this scenario is so much poor in respect of Onion productivity. Here, the onion productivity in Tamil Nadu is showing a decreasing status which is accounted for 148 per cent reduction than the all India status. This is very poor performance in respect of Onion and hence one has to take concerted efforts in diffusion of technology to the needed locale through appropriate technology transfer mechanisms. For that the Department of Horticulture and Plantation Crops of Government of Tamil Nadu and the KrishiVigyanKendras of Tamil Nadu Agricultural University should take proper efforts in enhancing the productivity level in Onion.

\section{Export of fruits from India}

Amidst the poor productivity of fruits and vegetables, India is taking efforts to export the fruits and vegetables of economic importance to gain foreign exchange earnings. The details of exports in a decade of time were subjected to growth rate analysis and the exportable quantity during the year 2020-21 was predicted and the details are presented in Table 11. Apple was exported to different destinations which are arrived at 26 thousand tonnes during the year 2006-07. But the same 
quantity was reduced over years and showing fluctuations in between and has reached the export quantity to the level of 22550 tonnes during the year 2016-17 and showed a negative growth rate of 4.39 which has resulted in poor quantity of export visualized during the year 2021 which is accounted for 19707 tonnes. The decrease in quantity of export was mainly due to the increased demand for apple in the local market. However, Banana found to be dominated in the export scene of fruits which has gained 19.37 per cent of growth rate annually and it is expected to reach the level of 1.88 lakh tonnes by the year 2020-21.

The export of Grapes in a decade of time had generated an annual growth rate of 6.31. With that growth, the prediction of export quantity of Grapes during the year 2020-21 was arrived at 2.38 lakh tonnes. Whereas the trend is totally different in the case of Mango export. Mango export had faced a negative annual growth rate of 3.02 and has the possible quantity of export during the year 2020-21 was found to be 47 thousand tonnes. Whereas, the Mango export during 2006-07 was 79 thousand tonnes and showing a fluctuation in export of Mango. It might be due to the export standards fixed by the European Nations were unmet by the traders. However, the orange export has witnessed a positive growth of 5.52 per cent and the export during the year 202021 will be 56 thousand tonnes. The reasons for the negative growth in the export of Mango and Apple need to be analyzed by the Agricultural and Processed Food Products Export Development Authority (APEDA) and do the needful to the trade issues raised in respect of Mango and Apple.

\section{Export of vegetables from India}

Among the export of Fruits, Apple and Mango had a negative growth. It indicated that the export trade in respect of these two is not incommensurate with the production. It might be due to the poor post-harvest initiatives and production issues associated with these two fruits. However, export of vegetables also from India during the present decade is found to be Improving and hence these details are analyzed and the results are presented in Table 12.

Among the vegetables, the export of Tomatoes and Potatoes had generated the highest annual growth rate which is accounted for 16.92 per cent and 15.90 per cent respectively resulted in possible export of 5.32 lakh tonnes of Potatoes and 4.28 lakh tonnes of Tomatoes during the year 2020-21 (Table 12). According to Sekhar (2018), the Tomato should be whole, fresh in appearance, sound, produce should not be affected by rotting and bruising marks, free from crack, clean, practically it should be free of any visible foreign matters, free of abnormal external moisture, free of pests affecting the general appearance are the quality aspects while considering for export. The growth of Pea is found to be very less but positive when one examine the vegetables. It might be due to poor area under Pea cultivation and hence poor export to the demanding destinations. Cauliflower and Onion export in a decade of time showed a positive growth of 4.98 per cent and 3.02 per cent respectively had possible achievement in the export of Cauliflower and Onion to the level of 1500 $\mathrm{kgs}$ and 26.42 lakh tonnes. From this one could understand that the Potatoes, Tomatoes and Onion were the leaders in the export markets.

India is the topper in producing Banana globally. China is found to be the leader in production of Onion followed by India. Area under Fruits especially Banana is increasing over a period of time and the production is also found to increase. Similarly the productivity is also increasing over the years 
due to the intervention of National Horticulture Mission. In India, the average productivity of Banana is arrived at 34.85 tonnes per ha. But Tamil Nadu is capable of securing higher level of productivity which is arrived at 33.28 tonnes per ha.

State wise data on productivity outlined that the Maharashtra and Gujarat are states whom are leaders in achieving highest productivity. In respect of export of fruits and vegetables, apple and mango faced a negative growth in a decade of time from 2006-07 to 2016-17. Whereas, all the vegetables have showed a positive growth. Among the vegetables, Potatoes and Tomatoes have exhibited higher growth and the Pea alone generated very poor growth rate in respect of exportable quantity abroad. In this respect, the APEDA should take special effort in sorting the deficiencies and do the needful to enhance the export growth.

\section{References}

Government of India (2018) "Indian Horticulture Data Base of Various Issues", (Ministry of Agriculture, Department of Agriculture and Farmers Welfare: New Delhi).

Muthupadi, P.C. Sekharand K.R. Karunakaran (2018). Production and Export Performance of Spices from India", Horticulture International Journal, 2(6): 425-430.

Sekhar, C., and A. Vidhyavathi (2018) "Economics of Precision Farming", (MJP Publishers: Chennai) p. 400.

\section{How to cite this article:}

Ananthakumar, A., C. Sekhar and Murugananthi, D. 2019. Global and National Scenario and Growth Trends in Area Production Productivity and Export of Fruits and Vegetables. Int.J.Curr.Microbiol.App.Sci. 8(11): 1787-1801. doi: https://doi.org/10.20546/ijcmas.2019.811.210 